\title{
Molecular detection of circulating cancer cells in the peripheral blood of patients with colorectal cancer by using membrane array with a multiple mRNA marker panel
}

\author{
CHING-SHENG YEH ${ }^{1,2}$, JAW-YUAN WANG ${ }^{1,3}$, CHAN-HAN WU $^{1}$, INN-WEN CHONG ${ }^{4,5}$, \\ FU-YEN CHUNG ${ }^{1}$, YUNG-HSIN WANG ${ }^{1}$, YA-PING YU ${ }^{1}$ and SHIU-RU LIN ${ }^{1}$ \\ ${ }^{1}$ MedicoGenomic Research Center, Kaohsiung Medical University; Departments of ${ }^{2}$ Laboratory Medicine, \\ ${ }^{3}$ Surgery Medicine, and ${ }^{4}$ Internal Medicine, Kaohsiung Medical University Hospital; \\ ${ }^{5}$ Kaohsiung Municipal Hsiao-Kang Hospital, Kaohsiung, Taiwan, R.O.C.
}

Received September 20,2005; Accepted November 11, 2005

\begin{abstract}
The objective of this study was mainly to evaluate the simultaneous detection of expression levels of a multiple mRNA marker panel in the peripheral blood of colorectal cancer (CRC) patients for use in complementary CRC diagnosis. Twenty-seven tumor tissue specimens and 80 peripheral blood specimens were collected from CRC patients. Firstly, the levels of multiple molecular markers in the tumor tissue and blood specimens were evaluated by using real-time quantitative PCR (RT-QPCR) and membrane array. The result of linear regression showed a high degree of correlation $(r=0.954$, $\mathrm{P}<0.0001)$ between the data of these two methods. CK-19 was the marker with the highest detection rate $(87.5 \%)$ in the peripheral blood, followed by CEA (82.6\%), REG4 (80.8\%), and then UPA $(80.0 \%)$ and TLAM1 $(80.0 \%)$. The levels of the six markers in the peripheral blood were extensively explored. In the 80 patients, the frequency of CK-19, CK-20, CEA, REG4, uPA, and TIAM1 mRNA overexpression was $82.5 \%(66 / 80), 78.8 \%(63 / 80), 82.5 \%$ (66/80), $80.0 \%$ (64/80), 78.8\% (63/80), and 80.0\% (64/80), respectively. Then, a panel combining these 6 mRNA markers was evaluated for its utility in the clinical diagnosis of CRC. The sensitivity, specificity, and accuracy of membrane array-based diagnostic method were $88.8 \%, 87.8 \%$, and $88.2 \%$, respectively; much higher than those of examinations with single markers. Finally, lymph node metastasis $(\mathrm{P}=0.024)$ and TNM stage $(\mathrm{P}=0.009)$ were found to be significantly correlated with overexpression of the multiple mRNA marker panel. The detection rates of stage-I and -II CRC by using the multi-marker membrane array were $54.5 \%(6 / 11)$ and $92.0 \%(23 / 25)$, respectively. In
\end{abstract}

Correspondence to: Dr Shiu-Ru Lin, MedicoGenomic Research Center, Kaohsiung Medical University, No. 100, Shin-Chuan 1st Road, Kaohsiung 80317, Taiwan, R.O.C.

E-mail: srlin@ms2.hinet.net

Key words: peripheral blood, colorectal cancer, membrane array, real-time Q-PCR, molecular markers, diagnosis conclusion, the results of the present study have shown that this innovative membrane array technique with a multiple mRNA marker panel can significantly improve the diagnosis rate of early colorectal cancer.

\section{Introduction}

Colorectal cancer (CRC) is a leading cause of morbidity and mortality in Europe and the USA. Each year, approximately 300,000 new cases and 200,000 deaths due to CRC are reported in these areas (1-3). CRC is also one of the most frequent malignancies and the third major cause of cancerrelated death in Taiwan, with over 7,000 new cases and 3,000 deaths per year (4). As several investigators have reported, approximately $40-50 \%$ of CRC patients who undergo a supposedly curative resection nevertheless subsequently develop metastatic disease, and die of their disease within 5 years $(5,6)$. Survival is closely related to the pathological stage of this disease. There is a dramatic difference in survival rates between patients with early-stage CRC and those with advanced CRC $(7,8)$. Thus, early diagnosis is imperative for obtaining a better therapeutic outcome and prognosis. Although promising advances in imaging technology and other diagnostic modalities have been achieved recently, early detection of CRC remains a challenge. For instance, radiological crosssectional imaging, such as computed tomography (CT) and magnetic resonance imaging (MRI), meets the required sensitivity (capable of detecting tumor nodules of $\geq 1 \mathrm{~cm}$ in diameter) as a screening tool, but can be ruled out due to high cost; and ultrasonography does not achieve the required sensitivity when used alone $(9,10)$. According to the report of Weidner et al (11), active angiogenesis may occur in breast cancer tissue growing to $2 \mathrm{~mm}$ in diameter. In a metastatic state, each gram of tumor may shed approximately $10^{6}$ cells into the blood vessel (12). Also, blood sampling is relatively easy. Therefore, disseminated tumor cells in peripheral blood were adopted as a target for early colorectal cancer detection in the present study.

In recent years, several highly sensitive methods have been developed to detect circulating tumor cells in the blood of patients with different types of malignancies, including flow 
cytometry $(13,14)$, RT-PCR (15-17), immunohistochemistry $(18,19)$, and Q-PCR $(16,20)$. Despite having been proven to be powerful tools, these techniques are limited to monitor only one or a few markers for each specimen in a single test. In the present study, we exploited membrane array, previously established in our laboratory, as the technological platform for CRC diagnosis (21). This innovative technique could not only monitor multiple markers simultaneously, but also displayed high sensitivity: only 5 cancer cells per $1 \mathrm{ml}$ of blood could be positively detected. Relying on this technological platform, we intended to develop a feasible, highly sensitive, high-throughput CRC diagnosis technique which could screen a panel of informative markers within a short period of time.

The present study was based on the analytic results of TGS-4K array in our previous report (22). By far, a number of mRNA markers including CK-19, CK-20, CEA, REG4, UPA, and TIAM1 have been demonstrated to be up-regulated in CRC cells, and thus widely used for the detection of CRC. Among these markers, CK-19, CK-20, and CEA are the three molecular markers most commonly studied and applied in clinical orientation (23-29). The REG4 gene, recently identified by Dieckgraefe et al, plays an import role in the onset of colorectal adenoma, and may be useful for the early diagnosis of CRC $(30,31)$. A large body of clinical data has indicated that high levels of uPA are associated with poor prognosis of CRC patients (32-34). TIAM1 is capable of activating Rac1 as a ubiquitous guanine nucleotide exchange factor and inducing membrane cytoskeleton-mediated cell shape changes, cell adhesion, and cell motility $(35,36)$.

To date, however, the correlation between the expression levels of these mRNA markers and the cancer progression stages of CRC patients requires further elucidation. In the present study, we exploited membrane array to quantitatively analyze the expression of CK-19, CK-20, CEA, REG4, uPA, and TIAM1 mRNA markers in the circulating tumor cells of patients with stage-I and -II (TNM classification) CRC. Hopefully, the goal of early CRC detection can be achieved through this innovative diagnosis technique established in this study and, in turn, improve the efficacy of therapies in managing this malignancy.

\section{Patients and methods}

Patients and samples. Eighty patients undergoing elective surgery for CRC at the Department of Surgery of Kaohsiung Medical University Hospital between April 2003 and May 2005 were enrolled in this study. Forty-two were males and thirty-eight were females. The mean age was 63.24 years (range 27-95 years). Of the 80 patients, 11 were subsequently diagnosed according to the TNM classification system with stage-I, 25 with stage-II, 36 with stage-III, and 8 with stage-IV CRC (Table I). Among 80 pairs of CRC tissue and adjacent normal colorectal tissue surgically removed from the patients, 27 were randomly selected for further analysis, of which 7 presented with stage-I, 7 with stage-II, 7 with stage-III, and 6 with stage-IV disease (data not shown). All surgical tissue samples, upon acquisition, were frozen instantly in liquid nitrogen, and then stored in a $-80^{\circ} \mathrm{C}$ freezer until analysis. Additionally, a 5-ml sample of peripheral blood was obtained from each of the $80 \mathrm{CRC}$ patients at the time of surgical
Table I. Demographic and clinicopathological characteristics of CRC patients.

Numbers of patients

Total cases

80

Age (year)

$<60$

$\geq 60$

Gender

Male

Female

Tumor size ${ }^{\mathrm{a}}$

$<2 \mathrm{~cm}$

$\geq 2 \mathrm{~cm}$

Tumor differentiation

Well

Moderate

Poor

Depth of tumor invasion

$\mathrm{T} 1$

$\mathrm{T} 2$

T3

T4

Lymph node metastasis

Absent

Present

TNM stage

I

II

III

36

IV

${ }^{a}$ Tumor size was measured for invasive area by histological examination.

resection and from 98 healthy volunteers serving as normal controls. To prevent contamination of epithelial cells, peripheral blood samples were obtained through a catheter inserted into a peripheral vessel, and the first $5 \mathrm{ml}$ of blood were discarded. Written informed consent was obtained from all subjects and/or guardians for use of their tissue and blood samples. Sample acquisition and subsequent use were also approved by the Institutional Review Board (IRB) of the Kaohsiung Medical University. Clinical stages and pathological features of primary tumors were defined according to the criteria of the American Joint Commission on Cancer (AJCC) (37).

Total RNA extraction and first-strand cDNA synthesis. Total RNA was isolated from patients' blood and tissue specimens 
Table II. Primers for real-time Q-PCR and oligonucleotides for membrane arrays.

\begin{tabular}{lll}
\hline Primers & \multicolumn{1}{c}{ Forward primer $\left(5^{\prime} \rightarrow 3^{\prime}\right)$} & \multicolumn{1}{c}{ Reverse primer $\left(5^{\prime} \rightarrow 3^{\prime}\right)$} \\
\hline CK-19 & ATGAAAGCTGCCTTGGAAGA & TGATTCTGCCGCTCACTATCAG \\
CK-20 & CTGAATAAGGTCTTTGATGACC & ATGCTTGTGTAGGCCATCGA \\
CEA & AACTGGTGTCCCGGATTCA & ATATTCTTGCTCCTTGCA \\
REG4 & CCAAACAGATTTGCAGATCAAGGA & TGCAGGAGTTAGCAGAATCTTGAT \\
uPA & CTAGGCCTGGGGAAACACAATTACTGCAGG & TGTCTACACGAGGGTCTCACACTTCCTGGA \\
TIAM1 & AAGACGTACTCAGGCCATGTCC & GACCCAAATGTCGCAGTCAG \\
B-actin & GCATCCACGAAACTACCTTC & CAGGAGGAGCAATGATCTTG \\
\hline Oligonucleotides for membrane array $\left(5^{\prime} \rightarrow 3^{\prime}\right)$ & \\
\hline CK-19 & GTATCCGTGTCCTCCGCCCGCTTTGTGTCCTCGTCCTCCT \\
CK-20 & TCCGCATCTCCAACTCCAGACACACGGTGAACTATGGGAGCGATCTCACA \\
CEA & CCGCAGTATTCTTGGCGTATCAATGGGATACCGCAGCAACACACACAAGTTC \\
REG4 & GAAGCCAGCACCATAGCAGAGTACATAAGTGGCTATCAGAGAAGCCAGCC \\
uPA & CTCCAAAGGCAGCAATGAACTTCATCAAGTTCCATCGAACTGTGACTGTCTAAATGGAGGAACATG \\
TIAM1 & ATGCTGACCGCTTCAAGCTCTACAGTGCCTTCTGCGCCATCCACACAAAA \\
B-actin & TCATGAAGTGTGACGTGGACATCCGCAAAGACCTGTACGCCAACACAGTGCTGTC \\
\hline
\end{tabular}

using Isogen ${ }^{\mathrm{TM}}$ (Nippon Gene Co., Ltd., Toyama, Japan) and the QiaAmp ${ }^{\circledR}$ RNA blood mini kit (Qiagen Inc., Valencia, CA, USA) according to the manufacturer's instructions (38). The RNA concentration was determined spectrophotometrically on the basis of absorbance at $260 \mathrm{~nm}$ (Beckman, DU800, USA). First-strand cDNA was synthesized from total RNA by using a RT-PCR kit. Reverse transcription was carried out in a reaction mixture consisting of $1 \mathrm{X}$ transcription optimized $5 \mathrm{X}$ buffer, $25 \mu \mathrm{g} / \mathrm{ml}$ Oligo(dT) 15 primer, $100 \mathrm{mmol} / \mathrm{l}$ PCR nucleotide mix, $200 \mu \mathrm{mol} / 1 \mathrm{M}-\mathrm{MLV}$ reverse transcriptase, and $25 \mu 1$ of recombinant $\mathrm{RNasin}{ }^{\circledR}$ ribonuclease inhibitor (Promega). The reaction mixtures with RNA were incubated at $42^{\circ} \mathrm{C}$ for longer than $2 \mathrm{~h}$, heated to $95^{\circ} \mathrm{C}$ for $5 \mathrm{~min}$, and then stored at $-80^{\circ} \mathrm{C}$ until analysis.

Oligo membrane array preparation. We used Visual OMP3 (DNA Software Inc.) to design oligonucleotide probe sequences for target genes and $\beta$-actin served as an internal control (Table II). The newly synthesized oligonucleotide fragments were dissolved in dis-water to a concentration of $20 \mathrm{mM}$ and then applied to a BioJet Plus 3000 nanoliter dispense system, which blotted sequentially the 6 target oligonucleotides and B-actin $(0.05 \mu 1$ per spot and $1.5 \mathrm{~mm}$ between spots $)$ on SuperCharge nylon membrane in triplicate. DMSO was also dispensed onto the membrane as a blank control. After rapid drying and crosslinking procedures, the preparation of colorectal cancer diagnostic membrane array was accomplished (21).

Preparation of digoxigenin-labeled cDNA targets and hybridization. First-strand cDNA targets for hybridization were produced by using SuperScript II reverse transcriptase (Gibco-BRL) in the presence of digoxigenin (DIG)-labeled UTP (Roche Diagnostics GmbH, Penzberg, Germany). After procedures of prehybridization and blocking, the gene chips were subjected to hybridization. The lifts were covered with the Express Hyb Hybridization Solution (BD Biosciences, Palo Alto, CA, USA) containing DIG-11-UTP-labeled cDNA probes, and then incubated with alkaline phosphataseconjugated anti-digoxigenin antibody (Roche Diagnostics). For hybridization, the arrays were incubated at $42^{\circ} \mathrm{C}$ for $12 \mathrm{~h}$ in a humid chamber. After washing, the arrays were exposed to light. For signal detection, the gene chips were incubated in chromogen solution containing nitroblue-tetrazolium and 5-bromo-4-chloro-3-indoyl-phosphate (NBT/BCIP) for $15 \mathrm{~min}$. The hybridize arrays were then scanned with an Epson Perfection 1670 flat bed scanner (Seiko Epson Corp., Naganoken, Japan). Subsequent quantification analysis of each spot's intensity was carried out by using AlphaEase ${ }^{\circledR}$ FC software (Alpha Innotech Corp., San Leandro, CA, USA). Spots consistently carrying by a factor of two or more were taken as differentially expressed. These array analysis tools facilitated the measurement of relative gray levels of objects in a uniformly spaced array, such as dot blots. A deformable template extracted the gene spots and quantified their expression levels by the integrated intensity of the spot after background subtraction. The fold ratio for each gene was calculated as follows: spot intensity ratio $=($ mean intensity of target gene $) /($ mean intensity of $\beta$-actin).

Cell culture. Human colon adenocarcinoma cell line SW480 was obtained from American Type Culture Collection (ATCC, Rockville, MD, USA). The cells were maintained in Leibovitz's L-15 medium (Gibco Life Sciences, BRL, Grand Island, NY) supplemented with $10 \%$ of fetal calf serum (FCS) at $37^{\circ} \mathrm{C}$ in humidified atmospheric air without $\mathrm{CO}_{2}$ addition. When grown to confluent monolayer, the cells were harvested by washing the dishes once with phosphate-buffered saline (PBS), $\mathrm{pH}$ 7.3, and then incubated in PBS containing $0.53 \mathrm{mmol} / \mathrm{l}$ EDTA and $0.05 \%$ trypsin (Gibco) for $10-15 \mathrm{~min}$ at $37^{\circ} \mathrm{C}$. The trypsinized cells were counted and cell viability was assessed by trypan blue dye exclusion. 
A

\begin{tabular}{|c|c|c|c|c|c|c|c|c|}
\hline CK-19 & CK-20 & CEA & REG4 & uPA & TIAM1 & Blank & TB & $\beta$-actin \\
\hline CK-19 & CK-20 & CEA & REG4 & uPA & TIAM1 & Blank & TB & $\beta$-actin \\
\hline CK-19 & CK-20 & CEA & REG4 & uPA & TIAM1 & Blank & TB & $\beta$-actin \\
\hline
\end{tabular}

B

(a) Colorectal cancer

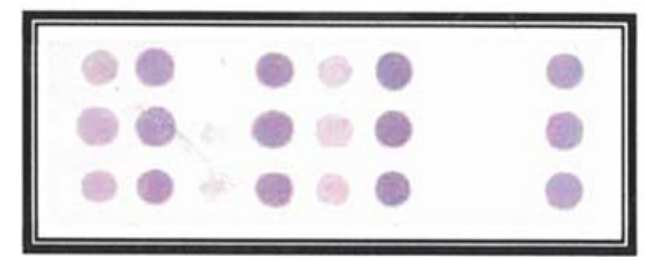

(b) Control individual

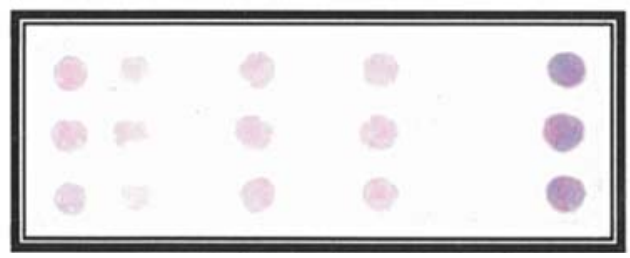

Figure 1. Images of membrane array assay. (A) Positions of oligonucleotide probes on membrane array. CK-19, cytokeratin 19; CK-20, cytokeratin 20; CEA, carcinoembryonic antigen; REG4, regenerating islet-derived family, member 4; uPA, plasminogen activator, urokinase; TIAM1, T-cell lymphoma invasion and metastasis 1; and TB, Mycobacterium tuberculosis (negative control). (B) Detection of disseminated cancer cells in peripheral blood by membrane array. (a), CRC patient and (b), normal person.

Sensitivity assay of membrane array. To determine the sensitivity of membrane array assay for CRC cells, SW480 cells of $100,25,10$, and 5 in number were added to $5 \mathrm{ml}$ of normal peripheral blood. The specimens were subjected to RNA isolation with sequential first-strand cDNA isolation and Dig-dUTP labeling. The Dig-labeled cDNA was then applied to the membrane for hybridization.

Real-time quantitative PCR assay. Real-time Q-PCR was performed in a Rotor-Gene 2070 thermocycler (Corbett Research Inc.). The reaction mixture contained $2 \mu 1$ of $20 \mathrm{mM} \mathrm{dNTP}$, $2 \mu 1$ of $30 \mathrm{mM} \mathrm{MgCl} 2,2 \mu 1$ of $20 X$ SYBR-Green, $2 \mu 1$ of $1 \mu \mathrm{M}$ forward primer, $2 \mu \mathrm{l}$ of $1 \mu \mathrm{M}$ reverse primer, $4 \mu 1$ of nuclease free water, $2 \mu \mathrm{l}$ of $80-100 \mathrm{ng} / \mathrm{ml} \mathrm{cDNA}$, and $2 \mu \mathrm{l}$ of $1 \mathrm{U} / \mu \mathrm{l}$ polymerase. PCR conditions were as follows: 35 cycles of denaturation at $95^{\circ} \mathrm{C}$ for $20 \mathrm{sec}$, annealing at $60^{\circ} \mathrm{C}$ for $20 \mathrm{sec}$, and extension at $74^{\circ} \mathrm{C}$ for $40 \mathrm{sec}$. PCR products (i.e., synthesized dsDNA) were quantified by measuring the fluorescent intensity at the end of each amplification cycle. The primers used for real-time Q-PCR are summarized in Table II.

Statistical analysis. All data were analyzed using Statistical Package for the Social Sciences version 11.5 software (SPSS Inc., Chicago, IL). The two-sided $\chi^{2}$ test and the Fisher exact test were used to compare clinicopathological parameters between mRNA marker-positive patients and mRNA markernegative patients. Receiver operating characteristics (ROC) curve analyses were carried out to determine the sensitivity and specificity for each mRNA marker (39). The cut-off values for each mRNA marker were set at points representing the highest accuracy of analysis (minimal false-negative and falsepositive results). The difference between data obtained by membrane array and real time Q-PCR was calculated by using linear regression and Pearson's correlation. A P-value of less than 0.05 was considered to be statistically significant.

\section{Results}

Demography of the study population and correlation between detection data of different methods in mRNA expression levels. Peripheral blood was collected from both $80 \mathrm{CRC}$ patients and 98 healthy volunteers following a standardized procedure. The demographic data and clinicopathological characteristics of all patients are summarized in Table I. The analysis of histological types showed that $3 \mathrm{CRC}$ tissue specimens were identified to be well-differentiated carcinoma, 64 to be moderately-differentiated carcinoma, and 13 to be poorlydifferentiated carcinoma. Of the 80 patients, 11 were subsequently diagnosed with stage-I, 25 with stage-II, 36 with stage-III, and 8 with stage-IV CRC. Firstly, total RNA was isolated from blood specimens, and then converted to cDNA, sequentially labeled by Dig-dUTP for membrane hybridization and chromogenesis. Fig. 1 shows the result of membrane array hybridization. Fig. 1A charts the corresponding positions of oligonucleotide probes on membrane array. Fig. 1B(a) and (b) are representative dot patterns of a normal control and a CRC patient, respectively. By comparing the two patterns, it is clear that CK-19, CK-20, CEA, REG4, uPA, and TIAM1 were differentially expressed in CRC. Whether or not there were differences between membrane array data and real-time Q-PCR 
Table III. Frequency of mRNA marker overexpression in tumor tissue and peripheral blood of 27 patients with colorectal cancer.

\begin{tabular}{lccc}
\hline & \multicolumn{2}{c}{ Overexpression of markers } & \\
\cline { 2 - 3 } mRNA markers & $\begin{array}{c}\text { Tissue } \\
(\%)\end{array}$ & $\begin{array}{c}\text { Blood } \\
(\%)\end{array}$ & $\begin{array}{c}\text { Blood/tissue } \\
(\%)\end{array}$ \\
\hline CK-19 & $24(88.9)$ & $21(77.8)$ & $21 / 24(87.5)$ \\
CK-20 & $24(88.9)$ & $19(70.4)$ & $19 / 24(79.2)$ \\
CEA & $26(96.3)$ & $21(77.8)$ & $21 / 26(82.6)$ \\
REG4 & $26(96.3)$ & $21(77.8)$ & $21 / 26(80.8)$ \\
uPA & $25(92.6)$ & $20(74.0)$ & $20 / 25(80.0)$ \\
TIAM1 & $25(92.6)$ & $20(74.1)$ & $20 / 25(80.0)$
\end{tabular}

${ }^{a}$ mRNA marker overexpression in the peripheral blood was not found in cases showing no evidence of mRNA marker overexpression in colorectal tumor. The blood-tissue ratio represented the relative detection rate of overexpression for a particular marker in the peripheral blood of colorectal cancer patients showing overexpression of the marker in tumor tissue.

data in levels of CK-19, CK-20, CEA, REG4, uPA, and TIAM1 mRNA expression in the peripheral blood of CRC patients were further statistically analyzed.
Differential expression of $m R N A$ markers in tumor tissue and circulating cancer cells in the peripheral blood of CRC patients. The expression of these molecular markers in the tumor tissue and peripheral blood of CRC patients was detected. In the tumor tissue of $27 \mathrm{CRC}$ patients, the frequency of CK-19, CK-20, CEA, REG4, uPA, and TIAM1 mRNA overexpression was $88.9 \%(24 / 27), 88.9 \%(24 / 27), 96.3 \%$ (26/27), 96.3\% (26/27), 92.6\% (25/27), and 92.6\% (25/27), respectively. Of the patients overexpressing each of these mRNA markers in their tumor tissue, $87.5 \%, 79.2 \%, 82.6 \%$, $80.8 \%, 80.0 \%$, and $80.0 \%$ also displayed overexpressed CK-19, CK-20, CEA, REG4, uPA, and TIAM1 mRNA in their peripheral blood, respectively (Table III). This suggested that the 6 mRNA markers had a great potential to be detected in the peripheral blood of CRC patients whose tumor tissue overexpressed the respective genes.

Consistency between data of membrane array and real-time $Q-P C R$. First, the ROC curves for the six mRNA markers indicated there was a high consistency between the data of membrane array and real-time Q-PCR (Fig. 2). Table IV summarizes the sensitivity and specificity of the two methods for each mRNA marker. The sensitivity and specificity of membrane array for the mRNA markers ranged from $78.8 \%$ to $82.5 \%$ and from $81.6 \%$ to $99.0 \%$, respectively. The sensitivity and specificity of real-time Q-PCR ranged from $70.0 \%$ to
A

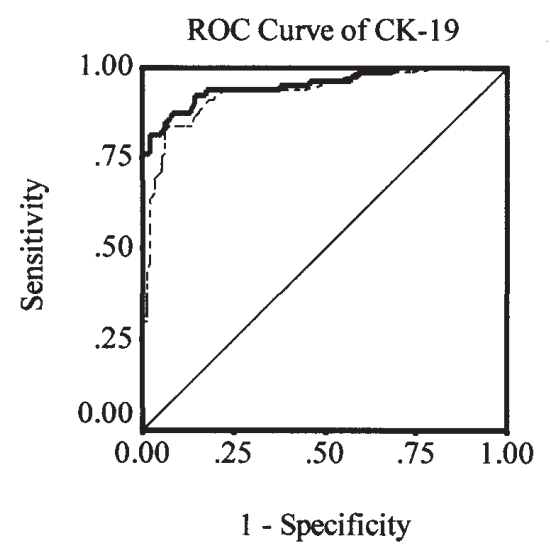

D

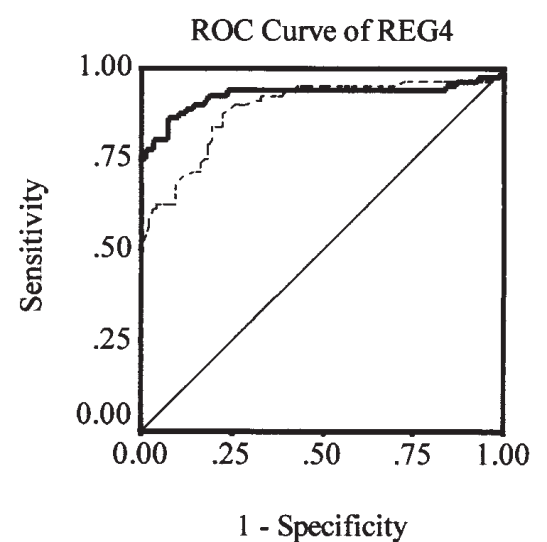

B

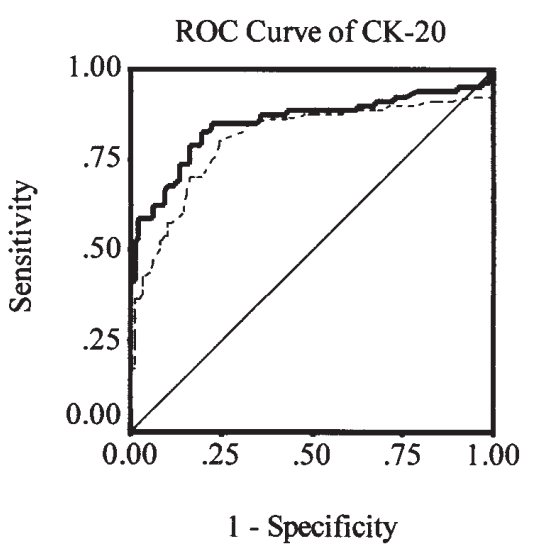

E

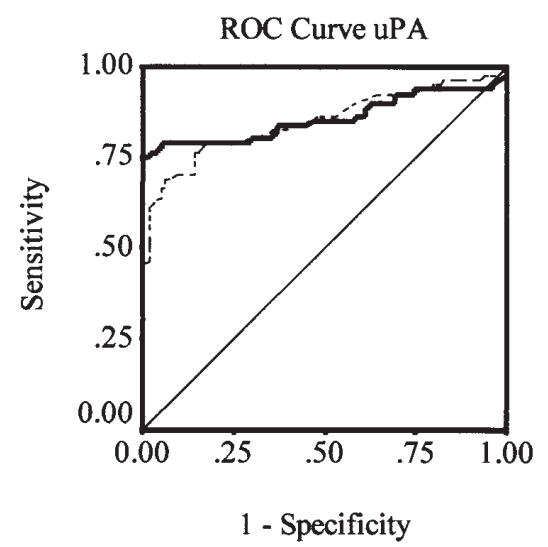

C

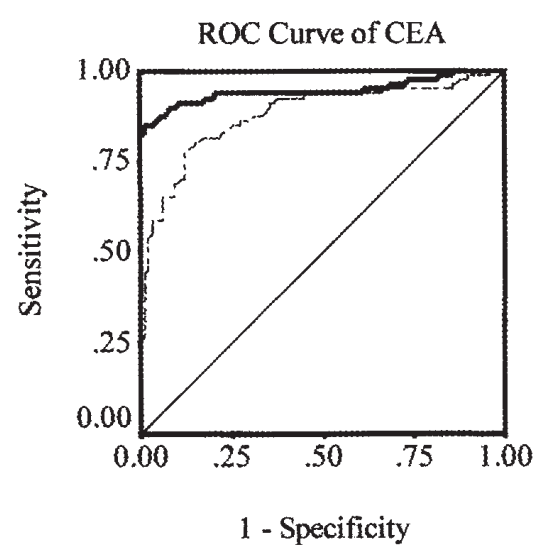

$\mathbf{F}$

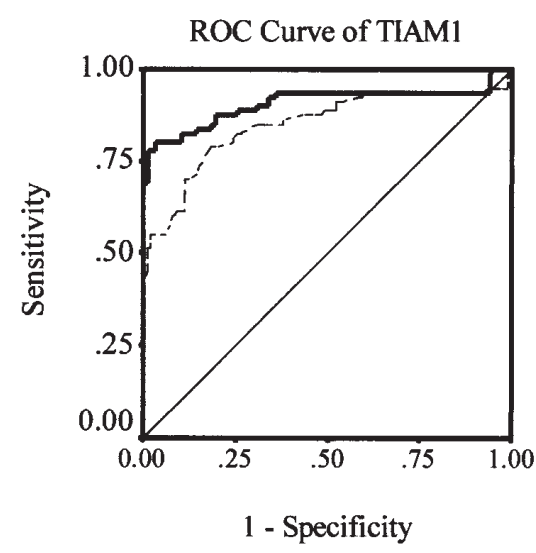

Figure 2. Receiver operating characteristic (ROC) curve analyses for optimum cut-off value, sensitivity, and specificity for mRNA markers: influence of control group. (A-F), CK-19, CK-20, CEA, REG4, uPA, and TIAM1; dashed curve, real-time Q-PCR; solid curve, membrane array. 
Table IV. Cut-off value and estimates of sensitivity and specificity for six mRNA markers in peripheral blood of eighty patients measured by two different methods.

\begin{tabular}{|c|c|c|c|c|}
\hline Methods & $\mathrm{AUC}^{\mathrm{a}}$ & $\begin{array}{l}\text { Cut-off } \\
\text { value }^{\mathrm{b}}\end{array}$ & $\begin{array}{c}\text { Sensitivity } \\
(\%)\end{array}$ & $\begin{array}{c}\text { Specificity } \\
(\%)\end{array}$ \\
\hline \multicolumn{5}{|l|}{ CK-19 } \\
\hline Membrane-array & 0.925 & 0.74 & 82.5 & 94.9 \\
\hline RT-QPCR & 0.932 & 0.49 & 78.8 & 93.9 \\
\hline \multicolumn{5}{|l|}{ CK-20 } \\
\hline Membrane-array & 0.852 & 0.53 & 78.8 & 81.6 \\
\hline RT-QPCR & 0.806 & 0.33 & 70.0 & 80.6 \\
\hline \multicolumn{5}{|l|}{ CEA } \\
\hline Membrane-array & 0.944 & 0.92 & 82.5 & 99.0 \\
\hline RT-QPCR & 0.879 & 0.57 & 77.5 & 87.8 \\
\hline \multicolumn{5}{|l|}{ REG4 } \\
\hline Membrane-array & 0.925 & 0.77 & 80.0 & 92.9 \\
\hline RT-QPCR & 0.888 & 0.47 & 77.5 & 81.6 \\
\hline \multicolumn{5}{|l|}{ uPA } \\
\hline Membrane-array & 0.857 & 0.86 & 78.8 & 93.9 \\
\hline RT-QPCR & 0.849 & 0.53 & 76.3 & 85.7 \\
\hline \multicolumn{5}{|l|}{ TIAM1 } \\
\hline Membrane-array & 0.908 & 0.73 & 80.0 & 89.8 \\
\hline RT-QPCR & 0.850 & 0.44 & 78.8 & 80.6 \\
\hline
\end{tabular}

${ }^{\mathrm{a}} \mathrm{AUC}$, area under the ROC curve. ${ }^{\mathrm{b}}$ The cut-off value is a normalized expression value, a ratio of the marker gene expression to the reference gene expression.

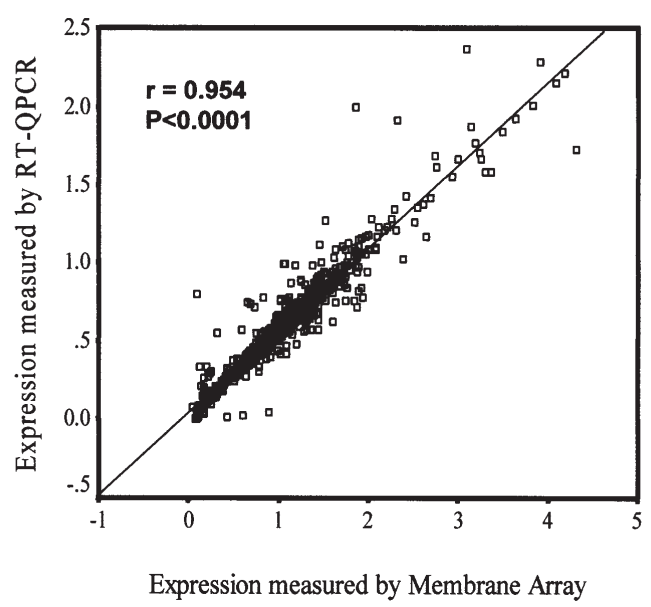

Figure 3. Liner regression and correlation analyses for 480 paired measures of gene expression by real-time Q-PCR and membrane array for six markers in the peripheral blood of 80 patients with colorectal cancer.

$78.8 \%$ and from $80.6 \%$ to $93.9 \%$, respectively (Table IV). The results indicated that both methods had no significant difference in sensitivity and specificity for these markers.

Second, 480 paired measures of expression levels of the six mRNA markers in the 80 CRC patients by the two methods

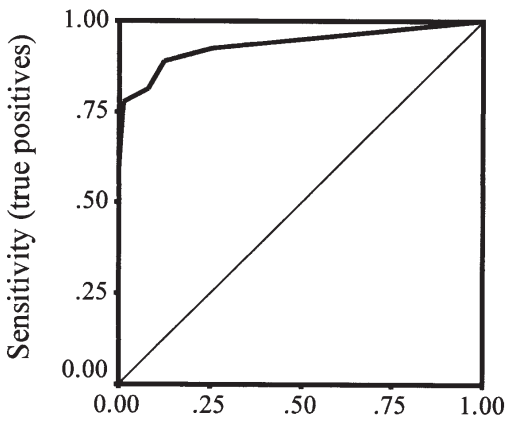

1 - Specificity (false positives)

Figure 4. ROC curve analysis of data obtained from membrane array. The outcome of membrane array was defined on the basis of number of markers overexpressed. Sensitivity and specificity of membrane array were determined to be $88.8 \%$ and $87.8 \%$, when 3 in the 6-marker panel were overexpressed. Therefore, a membrane array test was defined to be 'positive', when $\geq 3$ markers were overexpressed.

\begin{tabular}{|c|c|c|c|}
\hline Cell numbers in $5 \mathrm{ml}$ blood & \multicolumn{3}{|c|}{ Array image } \\
\hline 100 cells & $\div 0$ & : & 룽 \\
\hline 25 cells & $\begin{array}{l}0 \\
0 \\
0\end{array}$ & $\begin{array}{ll}- & 0 \\
- & 0\end{array}$ & - \\
\hline 10 cells & e & 훙 & 둥 \\
\hline 5 cells & & & - \\
\hline
\end{tabular}

Figure 5. Sensitivity of membrane array. Colorectal cancer cell line SW-480 in numbers of $100,25,10$, and 5 cells were separately added to 5 -ml aliquots of peripheral blood obtained from normal persons. The blood specimens were then subjected to membrane array analysis. The results showed that at least 25 cancer cells in $5 \mathrm{ml}$ of blood could be positively detected. For information on the arrangement of target genes on the membrane array, see Fig. 1A.

were subjected to linear regression and Pearson's correlation analyses. It demonstrated a high correlation coefficient of $\mathrm{r}=0.954$, which was highly significant $(\mathrm{P}<0.0001)$, between the two groups of data (Fig. 3). Therefore, the results of membrane array and real-time Q-PCR assays were highly consistent and correlated with each other. Our membrane array assay showed that the frequency of CK-19, CK-20, CEA, REG4, uPA, and TIAM1 mRNA overexpression in the peripheral blood of CRC patients was $82.5 \%$ (66/80), $78.8 \%$ (63/80), 82.5\% (66/80), $80.0 \%(64 / 80), 78.8 \%(63 / 80)$, and $80.0 \%$ (64/80), respectively (Table IV).

Sensitivity, specificity and detection limit of membrane arrays. ROC curve analysis applied to analyze data obtained by membrane array method with a panel combining the 6 
Table V. Clinicopathological features of CRC patients with or without mRNA expression in peripheral blood by membrane array.

\begin{tabular}{|c|c|c|c|c|c|c|c|c|c|c|c|c|c|c|c|c|c|c|}
\hline & \multicolumn{2}{|c|}{ CK-19 } & \multirow[b]{2}{*}{$\mathrm{P}^{\mathrm{b}}$} & \multicolumn{2}{|c|}{ CK-20 } & \multirow[b]{2}{*}{$\mathrm{P}^{\mathrm{b}}$} & \multicolumn{2}{|c|}{ CEA } & \multirow[b]{2}{*}{$\mathrm{P}^{\mathrm{b}}$} & \multicolumn{2}{|c|}{ REG4 } & \multirow[b]{2}{*}{$\mathrm{P}^{\mathrm{b}}$} & \multicolumn{2}{|c|}{ uPA } & \multirow[b]{2}{*}{$\mathrm{P}^{\mathrm{b}}$} & \multicolumn{2}{|c|}{ TIAM1 } & \multirow[b]{2}{*}{$\mathrm{P}^{\mathrm{b}}$} \\
\hline & + & - & & + & - & & + & - & & + & - & & + & - & & + & - & \\
\hline No. & 66 & 14 & & 63 & 17 & & 66 & 14 & & 64 & 16 & & 63 & 17 & & 64 & 16 & \\
\hline Age (year) & & & 0.864 & & & 0.315 & & & 0.652 & & & 0.156 & & & 0.670 & & & 0.813 \\
\hline$<60$ & 22 & 5 & & 23 & 4 & & 23 & 4 & & 24 & 3 & & 22 & 5 & & 22 & 5 & \\
\hline$\geq 60$ & 44 & 9 & & 40 & 13 & & 43 & 10 & & 40 & 13 & & 41 & 12 & & 42 & 11 & \\
\hline Gender & & & 0.426 & & & 0.292 & & & 0.166 & & & 0.057 & & & 0.292 & & & 0.823 \\
\hline Male & 36 & 6 & & 35 & 7 & & 37 & 5 & & 37 & 5 & & 35 & 7 & & 34 & 8 & \\
\hline Female & 30 & 8 & & 28 & 10 & & 29 & 9 & & 27 & 11 & & 28 & 10 & & 30 & 8 & \\
\hline Tumor size $^{\mathrm{a}}$ & & & 0.556 & & & 0.785 & & & 0.239 & & & 0.576 & & & 0.412 & & & 1.000 \\
\hline$<2 \mathrm{~cm}$ & 32 & 8 & & 31 & 9 & & 31 & 9 & & 33 & 7 & & 30 & 10 & & 32 & 8 & \\
\hline$\geq 2 \mathrm{~cm}$ & 34 & 6 & & 32 & 8 & & 35 & 5 & & 31 & 9 & & 33 & 7 & & 32 & 8 & \\
\hline \multicolumn{19}{|l|}{ Tumor } \\
\hline differentiation & & & 0.120 & & & 0.138 & & & 0.120 & & & 0.660 & & & 0.461 & & & 0.660 \\
\hline Well & 3 & 0 & & 1 & 2 & & 3 & 0 & & 3 & 0 & & 3 & 0 & & 3 & 0 & \\
\hline Moderate & 50 & 14 & & 52 & 12 & & 50 & 14 & & 51 & 13 & & 51 & 13 & & 51 & 13 & \\
\hline Poor & 13 & 0 & & 10 & 3 & & 13 & 0 & & 10 & 3 & & 9 & 4 & & 10 & 3 & \\
\hline \multicolumn{19}{|l|}{ Depth of } \\
\hline tumor invasion & & & 0.072 & & & 0.303 & & & 0.291 & & & 0.452 & & & 0.522 & & & 0.452 \\
\hline $\mathrm{T} 1$ & 4 & 1 & & 3 & 2 & & 4 & 1 & & 4 & 1 & & 4 & 1 & & 4 & 1 & \\
\hline $\mathrm{T} 2$ & 9 & 6 & & 10 & 5 & & 10 & 5 & & 10 & 5 & & 10 & 5 & & 10 & 5 & \\
\hline $\mathrm{T} 3$ & 50 & 7 & & 48 & 9 & & 49 & 8 & & 47 & 10 & & 46 & 11 & & 47 & 10 & \\
\hline $\mathrm{T} 4$ & 3 & 0 & & 2 & 1 & & 3 & 0 & & 3 & 0 & & 3 & 0 & & 3 & 0 & \\
\hline \multicolumn{19}{|l|}{ Lymph node } \\
\hline metastasis & & & $0.042^{\mathrm{c}}$ & & & $0.014^{\mathrm{c}}$ & & & $0.008^{c}$ & & & 0.124 & & & 0.191 & & & 0.124 \\
\hline Absent & 19 & 8 & & 17 & 10 & & 18 & 9 & & 19 & 8 & & 19 & 8 & & 19 & 8 & \\
\hline Present & 47 & 6 & & 46 & 7 & & 48 & 5 & & 45 & 8 & & 44 & 9 & & 45 & 8 & \\
\hline TNM stage & & & $0.003^{c}$ & & & $0.008^{c}$ & & & $0.042^{c}$ & & & 0.155 & & & 0.196 & & & 0.155 \\
\hline I & 5 & 6 & & 5 & 6 & & 6 & 5 & & 6 & 5 & & 6 & 5 & & 6 & 5 & \\
\hline II & 23 & 2 & & 18 & 7 & & 22 & 3 & & 21 & 4 & & 20 & 5 & & 21 & 4 & \\
\hline III & 30 & 6 & & 33 & 3 & & 30 & 6 & & 30 & 6 & & 30 & 6 & & 30 & 6 & \\
\hline IV & 8 & 0 & & 7 & 1 & & 8 & 0 & & 7 & 1 & & 7 & 1 & & 7 & 1 & \\
\hline
\end{tabular}

aTumor size was measured for invasive area by histological examination. ${ }^{\text {PPearson's }} \chi^{2}$ and Fisher's exact tests were used to compare the differences in proportion of mRNA marker overexpression between different groups of gender, age, tumor size, lymph node metastasis, tumor differentiation, depth of tumor invasion, and TNM stage. ${ }^{\mathrm{C}} \mathrm{P}-\mathrm{value}$ for test $<0.05$.

mRNA markers indicated that the sensitivity, specificity, and accuracy of this method for CRC detection were $88.8 \%$, $87.8 \%$, and $88.2 \%$, respectively, when the optimal cut-off point was 3 , i.e. 3 of the 6 mRNA markers were overexpressed in a single diagnostic test (Fig. 4). In order to explore the feasibility and sensitivity of membrane array, SW480 cells of $100,25,10$, and 5 in number were added to 5 -ml aliquots of whole blood obtained from normal persons. CRC cells were positively detected at a level as low as 25 cells $/ 5 \mathrm{ml}$ of blood (Fig. 5). This indicates that membrane array is a feasible and sensitive technique for detecting CRC cells circulating in the bloodstream.

Correlation between the results of membrane array and clinicopathological features of CRC patients. The application of membrane array with $6 \mathrm{mRNA}$ markers using the peripheral blood of an individual in complementary CRC diagnosis was then explored. For single mRNA markers, the overexpression of CK-19, CK-20, and CEA mRNA markers was correlated with lymph node metastasis, and the overexpression of CK-19, 
Table VI. Correlation between overexpression of multiple mRNA marker panel in the blood detected by membrane array and clinicopathological characteristics.

\begin{tabular}{lcc}
\hline & $\geq 3$ mRNA markers in overexpression \\
\cline { 2 - 3 } $\begin{array}{l}\text { Clinicopathological } \\
\text { characteristics }\end{array}$ & $\begin{array}{c}\text { Positive case } \\
(\%)\end{array}$ & P-value $^{\mathrm{a}}$ \\
\hline TNM stage & $54.5(6 / 11)$ & $0.009^{\mathrm{b}}$ \\
$\quad$ I & $92.0(23 / 25)$ & \\
II & $88.9(32 / 36)$ & \\
III & $100(8 / 8)$ & \\
IV & & $0.024^{\mathrm{b}}$ \\
Lymph node metastasis & $92.5(49 / 53)$ & \\
\multicolumn{2}{c}{ Present } &
\end{tabular}

aThe comparisons of mean numbers of overexpressed circulating mRNA markers among different pathological stages. ${ }^{\mathrm{P}} \mathrm{P}$-value for test $<0.05$.

CK-20, and CEA mRNA was correlated with the TNM stage of CRC (Table V). For the panel of 6 mRNA markers as a whole, a positive detection ( $\geq 3$ markers over-expressed) was significantly correlated with lymph node metastasis $(\mathrm{P}=0.024)$ and TNM stage $(\mathrm{P}=0.009)$ of CRC patients (Table VI). In patients with stage-I, -II, -III, and -IV CRC, the detection rates were $54.5 \%(6 / 11), 92.0 \%(23 / 35), 88.9 \%(32 / 36)$, and $100 \%$ (8/8), respectively. In CRC patients with lymph node metastasis, the detection rate was $92.5 \%$ (49/53). The overexpression of the other mRNA markers was not significantly correlated with any clinicopathological characteristics of the CRC patients (all $\mathrm{P}>0.05$ ).

\section{Discussion}

The goal of developing the membrane array-based diagnostic method detecting levels of tumor-associated mRNA markers in peripheral blood specimens was to monitor the risk of hematogenous tumor spread and circulating tumor burden in individuals. Our results showed that the membrane arraybased method positively detected circulating CRC cells at a density of 5 cells per $\mathrm{ml}$ of blood, in agreement with our previous study (21). It was also established that this innovative diagnosis technique achieved a high degree of sensitivity for disseminated tumor cells in the blood, comparable to those of Q-PCR and RT-PCR. Membrane array (40-43), however, is more time-saving and cost-effective than these two PCR-based techniques because it can simultaneously detect multiple target genes. In addition, ROC curve and linear regression analyses demonstrated a high consistency between the data of membrane array and real-time Q-PCR in the expression of 6 mRNA markers in the peripheral blood of CRC patients, indicating that membrane array has great potential for development and promotion in the application to clinical detection of circulating tumor cells in CRC patients. For single markers, the detection rate results obtained by using our membrane array and other methods described in the literature are rather heterogeneous.
Some studies found similar low detection rates for certain mRNA markers (44-46). In the present study, the detection rates for particular tumor-associated mRNA markers in the peripheral blood of CRC patients by using membrane array were between $78.8 \%$ and $82.5 \%$. The three leading markers with the highest sensitivity were CK-19, CK-20, and CEA mRNA. The prevalence of CEA mRNA expression in the peripheral blood of CRC patients in the literature varies considerably, ranging from $41 \%$ to $69 \%(19,46,47)$, apparently lower than that in our study. One possible explanation might be related to our blood sampling procedure carried out during the operation. Surgical manipulation is considered to enhance the release of tumor cells into the circulation.

A membrane array-based method simultaneously analyzing 6 mRNA markers could achieve a detection rate for CRC of $88.2 \%$ with a sensitivity of $88.8 \%$ and specificity of $87.8 \%$. For patients with stage-I and -II CRC, the detection rates of membrane array with multiple mRNA markers was raised to $54.5 \%$ and $92.0 \%$, respectively, much higher than the results in the reports of Guadagni et al and Hardingham et al $(45,48)$. The potential explanations included differences in target genes chosen, designs of oligonucleotide probes $(46,49)$, and detection techniques. Therefore, our findings demonstrated that membrane array simultaneously analyzing the expression of a panel of multiple mRNA markers in the peripheral blood of CRC patients could significantly enhance the detection rate of CRC in the clinical context. In addition, the correlation between the mRNA marker panel and clinicopathological characteristics of patients was explored. As our results showed, overexpression of a majority of mRNA markers in the panel was correlated with lymph node metastasis $(\mathrm{P}=0.024)$ and TNM stage $(\mathrm{P}=0.009)$ in the $\mathrm{CRC}$ patients. This implies that the innovative technological platform for CRC diagnosis can be also used to predict the prognosis of CRC patients. In conclusion, the detection of small numbers of CRC cells in patients' peripheral blood has become more and more important in the diagnosis of this malignancy. The membrane array-based diagnostic method developed in this study can simultaneously monitor levels of CK-19, CK-20, CEA, REG4, uPA, and TIAM1 mRNA markers in an individual's blood with high degrees of sensitivity and feasibility. This method offers a simple, relatively non-invasive, and promising tool for the detection of disseminated tumor cells in CRC patients. So, this innovative diagnosis technique could not only fulfill the demand for early detection of colorectal cancer but also be useful for monitoring the disease's progression. It is hopeful that the application of this membrane array-based method in clinical CRC diagnosis will contribute promising outcomes to post-operative follow-ups and therapeutic treatments for the disease.

\section{Acknowledgements}

This research was supported by a grant from the National Science Council of the Republic of China (NSC 93-2320-B037-042).

\section{References}

1. Brenes GA and Paskett ED: Predictors of stage of adoption for colorectal cancer screening. Prev Med 31: 410-416, 2000. 
2. Parkin DM: Global cancer statistics in the year 2000. Lancet Oncol 2: 533-543, 2001.

3. Ghafoor A, Jemal A, Cokkinides V, Cardinez C, Murray T, Samuels A and Thun MJ: Cancer statistics for African Americans. CA Cancer J Clin 52: 326-341, 2002.

4. Department of Health TEY, Republic of China: Health Statistics. 2002: Retrieved from Wold Wide Web site on May 25 (http:// www.doh.gov.tw/ufile/Doc/S06/91-19.xls).

5. Pohl C, Hombach A and Kruis W: Chronic inflammatory bowel disease and cancer. Hepatogastroenterology 47: 57-70, 2000.

6. Greenlee RT, Murray T, Bolden S and Wingo PA: Cancer statistics, 2000. CA Cancer J Clin 50: 7-33, 2000.

7. Wang HZ, Huang XF, Wang Y, Ji JF and Gu J: Clinical features, diagnosis, treatment and prognosis of multiple primary colorectal carcinoma. World J Gastroenterol 10: 2136-2139, 2004.

8. Zhang YL, Zhang ZS, Wu BP and Zhou DY: Early diagnosis for colorectal cancer in China. World J Gastroenterol 8: 21-25, 2002.

9. Lautenbach E, Forde KA and Neugut AI: Benefits of colonoscopic surveillance after curative resection of colorectal cancer Ann Surg 220: 206-211, 1994.

10. Khoury DA, Opelka FG, Beck DE, Hicks TC, Timmcke AE and Gathright JB Jr: Colon surveillance after colorectal cancer surgery. Dis Colon Rectum 39: 252-256, 1996.

11. Weidner N, Carroll PR, Flax J, Blumenfeld W and Folkman J: Tumor angiogenesis correlates with metastasis in invasive prostate carcinoma. Am J Pathol 143: 401-409, 1993.

12. Chang YS, Di Tomaso E, McDonald DM, Jones R, Jain RK and Munn LL: Mosaic blood vessels in tumors: frequency of cancer cells in contact with flowing blood. Proc Natl Acad Sci USA 97: 14608-14613, 2000.

13. Tsavellas G, Huang A, McCullough T, Patel H, Araia R and Allen-Mersh TG: Flow cytometry correlates with RT-PCR for detection of spiked but not circulating colorectal cancer cells Clin Exp Metastasis 19: 495-502, 2002

14. Cepowicz D, Stasiak-Barmuta A, Zalewski B and Piotrowski Z: Assessment expression of the adhesion molecules, CD134 and CD137, in patients with colorectal cancer by flow cytometry. Rocz Akad Med Bialymst 49 (suppl 1): 34-36, 2004.

15. Schuster R, Max N, Mann B, Heufelder K, Thilo F, Grone J, Rokos F, Buhr HJ, Thiel E and Keilholz U: Quantitative realtime RT-PCR for detection of disseminated tumor cells in peripheral blood of patients with colorectal cancer using different mRNA markers. Int J Cancer 108: 219-227, 2004.

16. Oberg AN, Lindmark GE, Israelsson AC, Hammarstrom SG and Hammarstrom ML: Detection of occult tumour cells in lymph nodes of colorectal cancer patients using real-time quantitative RT-PCR for CEA and CK20 mRNAS. Int J Cancer 111: 101-110, 2004.

17. Takayama O, Yamamoto $\mathrm{H}$, Ikeda $\mathrm{K}$, Ishida $\mathrm{H}, \mathrm{K}$ ato $\mathrm{T}$, Okuyama M, Kanou T, Fukunaga M, Tominaga S, Morita S, Fujie Y, Fukunaga H, Ikenaga M, Ikeda M, Ohue M, Sekimoto M, Kikkawa N and Monden M: Application of RT-PCR to clinical diagnosis of micrometastasis of colorectal cancer: a translational research study. Int J Oncol 25: 597-604, 2004.

18. Wahlberg SS, Schmeits J, Thomas G, Loda M, Garber J, Syngal S Kolodner RD and Fox E: Evaluation of microsatellite instability and immunohistochemistry for the prediction of germ-line MSH2 and MLH1 mutations in hereditary nonpolyposis colon cancer families. Cancer Res 62: 3485-3492, 2002.

19. Giuliani L, Ciotti M, Stoppacciaro A, Pasquini A, Silvestri I, De Matteis A, Frati L and Agliano AM: UDP-glucuronosyltransferases $1 \mathrm{~A}$ expression in human urinary bladder and colon cancer by immunohistochemistry. Oncol Rep 13: 185-191, 2005.

20. Chiu ST, Hsieh FJ, Chen SW, Chen CL, Shu HF and Li H: Clinicopathologic correlation of up-regulated genes identified using cDNA microarray and real-time reverse transcription-PCR in human colorectal cancer. Cancer Epidemiol Biomarkers Prev 14: 437-443, 2005.

21. Chen YF, Wang JY, Wu CH, Chen FM, Cheng TL and Lin SR: Detection of circulating cancer cells with K-ras oncogene using membrane array. Cancer Lett (In press).

22. Yeh CS, Wang JY, Cheng TL, Juan CH, Wu CH and Lin SR: Fatty acid metabolism pathway play an important role in carcinogenesis of human colorectal cancers by Microarray-Bioinformatics analysis. Cancer Lett (In press)

23. Hernandez BY, Frierson HF, Moskaluk CA, Li YJ, Clegg L, Cote TR, McCusker ME, Hankey BF, Edwards BK and Goodman MT: CK20 and CK7 protein expression in colorectal cancer: demonstration of the utility of a population-based tissue microarray. Hum Pathol 36: 275-281, 2005.
24. Na GW, Li J, He KJ, Li HH, Zhao XN, Li XW and Mi HN: CK20 mRNA expression in peripheral blood of patients with gastrointestinal carcinoma and its clinical significance. Ai Zheng 23: $1350-1353,2004$

25. Gradilone A, Gazzaniga P, Silvestri I, Gandini O, Trasatti L, Lauro S, Frati L and Agliano AM: Detection of CK19, CK20 and EGFR mRNAs in peripheral blood of carcinoma patients: correlation with clinical stage of disease. Oncol Rep 10: 217-222, 2003.

26. Lassmann S, Bauer M, Soong R, Schreglmann J, Tabiti K, Nahrig J, Ruger R, Hofler H and Werner M: Quantification of CK20 gene and protein expression in colorectal cancer by RTPCR and immunohistochemistry reveals inter- and intratumour heterogeneity. J Pathol 198: 198-206, 2002.

27. Ito S, Nakanishi H, Hirai T, Kato T, Kodera Y, Feng Z, Kasai Y, Ito K, Akiyama S, Nakao A and Tatematsu M: Quantitative detection of CEA expressing free tumor cells in the peripheral blood of colorectal cancer patients during surgery with realtime RT-PCR on a LightCycler. Cancer Lett 183: 195-203, 2002.

28. Miura M, Ichikawa Y, Tanaka K, Kamiyama M, Hamaguchi Y, Ishikawa T, Yamaguchi S, Togo S, Ike H, Ooki S and Shimada H: Real-time PCR (TaqMan PCR) quantification of carcinoembryonic antigen (CEA) mRNA in the peripheral blood of colorectal cancer patients. Anticancer Res 23: 1271-1276, 2003.

29. Xu D, Li XF, Jiang WZ, Cao J and Zheng S: Significance of CK20 mRNA expression in peripheral blood of colorectal cancer patients by real-time fluorescent quantitative RT-PCR. Zhejiang Da Xue Xue Bao Yi Xue Ban 33: 403-406, 2004.

30. Oue N, Mitani Y, Aung PP, Sakakura C, Takeshima Y, Kaneko M, Noguchi T, Nakayama $H$ and Yasui W: Expression and localization of Reg IV in human neoplastic and non-neoplastic tissues: Reg IV expression is associated with intestinal and neuroendocrine differentiation in gastric adenocarcinoma. J Pathol 207: 185-198, 2005

31. Zhang Y Lai M, Gu X, Luo M and Shao L: Reg IV, a differentially expressed gene in colorectal adenoma. Chin Med J (Engl) 116: 918-922, 2003

32. Wang XQ, Sun P and Paller AS: Gangliosides inhibit urokinasetype plasminogen activator (uPA)-dependent squamous carcinoma cell migration by preventing uPA receptor/alphabeta integrin/ epidermal growth factor receptor interactions. J Invest Dermatol 124: 839-848, 2005

33. Pakneshan P, Szyf M and Rabbani SA: Methylation and inhibition of expression of uPA by the RAS oncogene: divergence of growth control and invasion in breast cancer cells. Carcinogenesis 26: $557-564,2005$

34. Hundsdorfer B, Zeilhofer HF, Bock KP, Dettmar P, Schmitt M, Kolk A, Pautke C and Horch HH: Tumour-associated urokinasetype plasminogen activator (uPA) and its inhibitor PAI-1 in normal and neoplastic tissues of patients with squamous cell cancer of the oral cavity - clinical relevance and prognostic value. J Craniomaxillofac Surg 33: 191-196, 2005.

35. Chiu CY, Leng S, Martin KA, Kim E, Gorman S and Duhl DM: Cloning and characterization of T-cell lymphoma invasion and metastasis 2 (TIAM2), a novel guanine nucleotide exchange factor related to TIAM1. Genomics 61: 66-73, 1999.

36. Liu L, Wu DH and Ding YQ: Tiam1 gene expression and its significance in colorectal carcinoma. World J Gastroenterol 11 : 705-707, 2005 .

37. Fleming ID: AJCC/TNM cancer staging, present and future. J Surg Oncol 77: 233-236, 2001.

38. Chomczynski P and Sacchi N: Single-step method of RNA isolation by acid guanidinium thiocyanate-phenol-chloroform extraction. Anal Biochem 162: 156-159, 1987.

39. Weikert S, Krause H, Wolff I, Christoph F, Schrader M, Emrich T, Miller K and Muller M: Quantitative evaluation of telomerase subunits in urine as biomarkers for noninvasive detection of bladder cancer. Int J Cancer 117: 274-280, 2005.

40. Aerts J, Wynendaele W, Paridaens R, Christiaens MR, van den Bogaert W, van Oosterom AT and Vandekerckhove F: A realtime quantitative reverse transcriptase polymerase chain reaction (RT-PCR) to detect breast carcinoma cells in peripheral blood. Ann Oncol 12: 39-46, 2001.

41. Grunewald K, Haun M, Urbanek M, Fiegl M, Muller-Holzner E, Gunsilius E, Dunser M, Marth C and Gastl G: Mammaglobin gene expression: a superior marker of breast cancer cells in peripheral blood in comparison to epidermal-growthfactor receptor and cytokeratin-19. Lab Invest 80: 1071-1077, 2000 
42. Sabbatini R, Federico M, Morselli M, Depenni R, Cagossi K, Luppi M, Torelli G and Silingardi V: Detection of circulating tumor cells by reverse transcriptase polymerase chain reaction of maspin in patients with breast cancer undergoing conventionaldose chemotherapy. J Clin Oncol 18: 1914-1920, 2000.

43. Schoenfeld A, Kruger KH, Gomm J, Sinnett HD, Gazet JC, Sacks N, Bender HG, Luqmani Y and Coombes RC: The detection of micrometastases in the peripheral blood and bone marrow of patients with breast cancer using immunohistochemistry and reverse transcriptase polymerase chain reaction for keratin 19. Eur J Cancer 33: 854-861, 1997.

44. Patel H, Le Marer N, Wharton RQ, Khan ZA, Araia R, Glover C, Henry MM and Allen-Mersh TG: Clearance of circulating tumor cells after excision of primary colorectal cancer. Ann Surg 235: 226-231, 2002.

45. Guadagni F, Kantor J, Aloe S, Carone MD, Spila A, D'Alessandro R, Abbolito MR, Cosimelli M, Graziano F, Carboni F, Carlini S, Perri P, Sciarretta F, Greiner JW, Kashmiri SV, Steinberg SM, Roselli M and Schlom J: Detection of blood-borne cells in colorectal cancer patients by nested reverse transcription-polymerase chain reaction for carcinoembryonic antigen messenger RNA: longitudinal analyses and demonstration of its potential importance as an adjunct to multiple serum markers. Cancer Res 61: 2523-2532, 2001.
46. Wharton RQ, Jonas SK, Glover C, Khan ZA, Klokouzas A, Quinn H, Henry M and Allen-Mersh TG: Increased detection of circulating tumor cells in the blood of colorectal carcinoma patients using two reverse transcription-PCR assays and multiple blood samples. Clin Cancer Res 5: 4158-4163, 1999.

47. Castells A, Boix L, Bessa X, Gargallo L and Pique JM: Detection of colonic cells in peripheral blood of colorectal cancer patients by means of reverse transcriptase and polymerase chain reaction. Br J Cancer 78: 1368-1372, 1998.

48. Hardingham JE, Hewett PJ, Sage RE, Finch JL, Nuttall JD, Kotasek D and Dobrovic A: Molecular detection of blood-borne epithelial cells in colorectal cancer patients and in patients with benign bowel disease. Int J Cancer 89: 8-13, 2000.

49. Conzelmann M, Linnemann U and Berger MR: Molecular detection of clinical colorectal cancer metastasis: how should multiple markers be put to use? Int J Colorectal Dis 20: 137-146, 2005 . 